\title{
The Research of Evaluation of the Utilization Efficiency about Agricultural Information Resources on Internet
}

\author{
Ning ZHANG \\ School of Information, Financial and Economics of Guizhou University, Guiyang 550025 \\ zn8124@126.com
}

Keywords: Agricultural, Information resources, Utilization efficiency, Evaluation.

\begin{abstract}
With the development of information technology, there is the rapid growth trend of agricultural information resources on the Internet, which has great significance to evaluate the efficiency of utilization of agricultural information resources on internet. Take the 100 agricultural sites in Guizhou Province as the research object, establish the three level evaluation index system about evaluation of online agricultural information resources in Guizhou province, using input-output analysis model, to study and evaluate the reasonable utilization of agricultural information resources of Guizhou province, and gives the countermeasures and suggestions, to provide regional reference for the configuration and the construction of agricultural information resources.
\end{abstract}

\section{Introduction}

With the advance of agricultural informationization, the effective utilization of agricultural information resources on the Internet has become an important part of science and technology innovation, and the modernization of agriculture, mass informaiton from the domestic and foreign agricultural information sources on the Internet (WEB), has become the new resources for the agricultural workers, also become an important strategic resource Guizhou province agriculture and rural economic development.

Agricultural information resource on the Internet is to achieve maximum information share, digital agriculture information resources exist in a free, open and transparent manner on the internet.

The publishing time of agricultural information resources on Internet is uncertainty, broad geographical distribution, large quantity and variety, investigation and research faces the complexity of time, space and resource structure, which makes the high cost of data acquisition and exploitation [1]. At present, literature about development and utilization of agricultural information resources on Internet, most in the phase of theoretical study, a few empirical research data, just as China's Internet Development Research Center of the Internet development report, for the macro data summary analysis about time and space. Refer to the efficiency evaluation of agricultural information resources, index still has some defects, such as calculation theory is not perfect, statistical data is not complete, it is difficult to objectively reflect the utilization level of agricultural information resources, aiming at the efficiency of regional evaluation index, at present there is no domestic relevant research literature [2][3].

Study on the efficiency evaluation of development and utilization of Internet agricultural information resources in the Guizhou Province area is the basis of this paper, which solves the uniform description problem of agricultural information resources online time, space, and resource structure. From the user level and perspective of observation, do the efficiency evaluation, user survey and theoretical research of website agricultural information resources in Guizhou province. Taking 2001-2013 as a time range, selecting 100 agricultural sites from 4 cities, 2 autonomous prefectures, and 2 regions of Guizhou Province tests and analysis, do a survey and observation questionnaire from 60 agricultural core site. Integrating use of qualitative and quantitative analysis, establishing the evaluation index system and the input-output analysis model. 


\section{Establishment of utilization efficiency evaluation system about agricultural information resources on the Internet}

The evaluation system of utilization of agricultural online information resources in Guizhou province is divided into three level evaluation indexes. According to "Delphi method to construct weight" and "analytic hierarchy structure weight method", the index grades and scores mainly according to the investigation data calculation. "The Delphi method to construct weight" is also known as the expert method, through several revisions and feedback, to achieve expert opinion gradually obtain a group of satisfactory response of each index importance, using the "Delphi method to construct weight" thought, carrying on the questionnaire survey about persons refer to Guizhou agricultural information service, obtained evaluation index system and weight coefficient in the final. "Multi-layer weighting method" is the comprehensive evaluation index system according to the similarities and differences in indexes about the target side of the grouping, the reaction with a side of the index is classified as a class. This paper is based on "multi-layer weighting method", using "Delphi weighting method" to calculate the weights of indicators in each layer.

Through the utilization efficiency evaluation of online agricultural information resources, this can understand the construction, investment, distribution and quality of online agricultural information resources, so as to the situation of the construction of online agricultural information resources, providing the basis for judging the existence value. Therefore, the utilization efficiency evaluation index of agricultural information resources in the Internet should take full account of the network information resources construction environment, providers, network information resources access tools, methods and the information resources of the network users, evaluation from the point of view of system.

\section{The evaluation index and methods}

The establishment of evaluation of input-output model. From two angles of providers and users of the network information resources. For the network information resources providers, can understand the use of the agriculture network information rate, ensure the higher value and reliability of network agricultural information, and guide the better construction, include the construction of infrastructure, improve the quality and efficiency of their own, in order to better provide effective agricultural information, locking in customers, promote the utilization of agricultural information resources. For the agriculture network information resources users, can through the analysis of different industry site, understanding information distribution and quality construction of industry, and then obtain the effect of propagation effects and user behavior of agricultural information.

Therefore, based on the two angles of the providers and users of the network information resources, make website construction input and output the of the two contents as a first level evaluation index; website construction costs, development costs, external costs as the two level indicators of website construction investment, the effect of information dissemination effect and the user behavior also as the two index finally output; the three indicators of evaluation from the quantitative data obtained directly, as shown in Figure 2-1 [3].

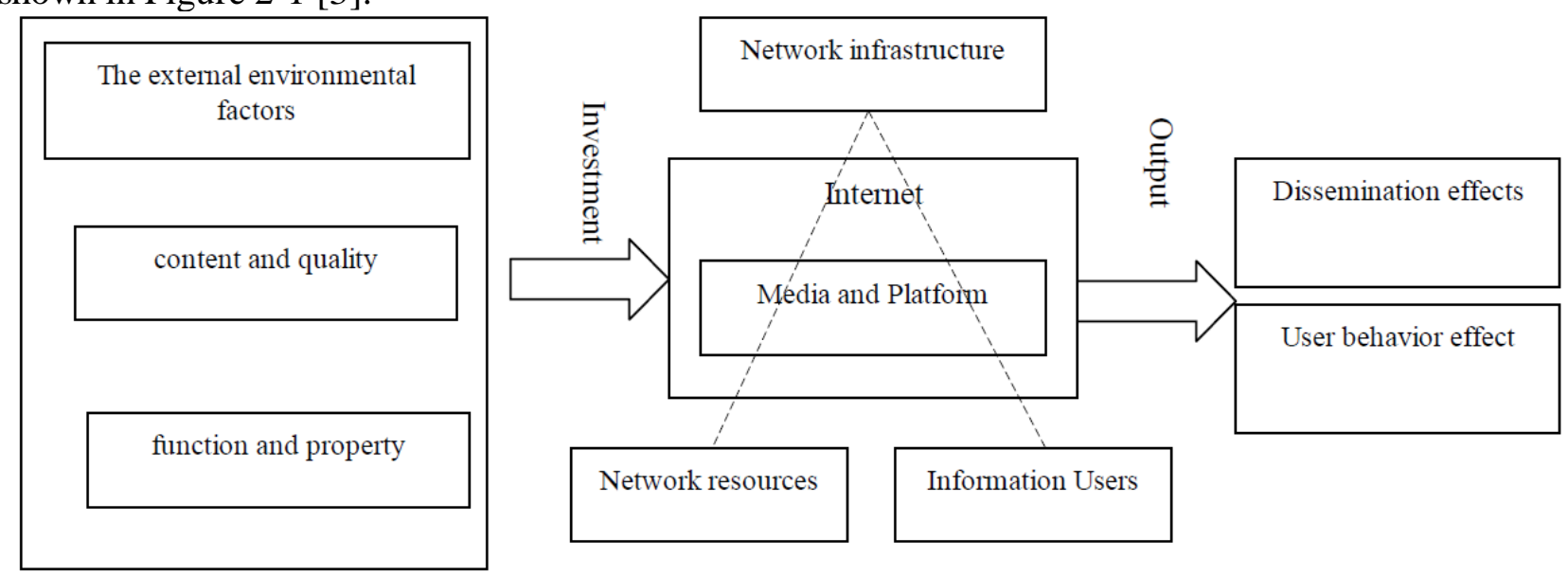

Figure2-1 the utilization efficiency of input output model of Agriculture network information resources 
Calculation weight of each index. The weight of indexes and two level index calculation mainly using "Delphi method to construct weight" and "analytic hierarchy process method ".

Calculation and grade partition of three level indicators. All levels of indexes are divided into five grades: very high, high, low, very low. Out of 10 points, five grades respectively assigned 10 points, 8 points, 6 points, 4 points, 2 points, the three level index score equal to at all levels index score is multiplied by the proportion of the indexes at all levels. Similarly, the specific scores of three level index under the two level indicators were multiplied by the corresponding sum reached the two level index score, after the calculation of all two levels of index score, with which multiplying scores of the two indicators can get the first level index score. Scoring is divided into three levels: high, medium and low. Score below 6 is low, the 6-8 is divided into, score of 8 points or more for high.

\section{The Calculation of index}

1) The calculation of three level index score

Table 2-1 The calculation table of three level index score

\begin{tabular}{|c|c|c|c|c|c|c|}
\hline $\begin{array}{c}\text { Grade of Three level } \\
\text { index }\end{array}$ & $\begin{array}{l}\text { very high } \\
10\end{array}$ & $\begin{array}{l}\text { high } \\
8\end{array}$ & $\begin{array}{c}\text { genearlly } \\
6\end{array}$ & $\begin{array}{c}\text { low } \\
4\end{array}$ & $\begin{array}{c}\text { very low } \\
2\end{array}$ & Total \\
\hline Construction scale & 0.07 & 0.32 & 0.38 & 0.17 & 0.06 & 6.34 \\
\hline $\begin{array}{c}\text { Function } \\
\text { construction }\end{array}$ & 0.04 & 0.44 & 0.29 & 0.16 & 0.07 & 6.42 \\
\hline $\begin{array}{l}\text { Technology } \\
\text { investment }\end{array}$ & 0.1 & 0.4 & 0.33 & 0.1 & 0.07 & 6.72 \\
\hline Website promotion & 0.07 & 0.39 & 0.36 & 0.13 & 0.05 & 6.6 \\
\hline News information & 0.03 & 0.4 & 0.36 & 0.15 & 0.06 & 6.38 \\
\hline $\begin{array}{c}\text { Science and } \\
\text { technology } \\
\text { information }\end{array}$ & 0.07 & 0.46 & 0.32 & 0.12 & 0.03 & 6.84 \\
\hline Policy information & 0.04 & 0.36 & 0.44 & 0.14 & 0.02 & 6.52 \\
\hline Market information & 0.08 & 0.37 & 0.41 & 0.13 & 0.01 & 6.76 \\
\hline $\begin{array}{l}\text { Internet penetration } \\
\text { rate }\end{array}$ & 0.07 & 0.35 & 0.38 & 0.14 & 0.06 & 6.46 \\
\hline Per capita GDP & 0.03 & 0.25 & 0.4 & 0.21 & 0.11 & 5.76 \\
\hline $\begin{array}{c}\text { Information } \\
\text { technology talents }\end{array}$ & 0.03 & 0.39 & 0.35 & 0.16 & 0.07 & 6.3 \\
\hline $\begin{array}{l}\text { The average daily } \\
\text { traffic }\end{array}$ & 0.06 & 0.27 & 0.45 & 0.17 & 0.05 & 6.24 \\
\hline Daily views & 0.03 & 0.28 & 0.45 & 0.2 & 0.04 & 6.12 \\
\hline Website ranking & 0.05 & 0.34 & 0.4 & 0.15 & 0.06 & 6.34 \\
\hline The website visit rate & 0.03 & 0.31 & 0.31 & 0.21 & 0.14 & 6.2 \\
\hline $\begin{array}{l}\text { The completeness of } \\
\text { the contents of } \\
\text { satisfaction }\end{array}$ & 0.04 & 0.35 & 0.38 & 0.18 & 0.05 & 6.3 \\
\hline Practical satisfaction & 0.02 & 0.46 & 0.32 & 0.15 & 0.05 & 6.05 \\
\hline $\begin{array}{c}\text { Content update } \\
\text { frequency } \\
\text { satisfaction }\end{array}$ & 0.06 & 0.42 & 0.37 & 0.1 & 0.05 & 6.68 \\
\hline
\end{tabular}

2) According to the above evaluation method, get the efficiency evaluation index of online agricultural information resources in Guizhou province, shown in table 2-2: 
Table 2-2 The evaluation index system of the utilization efficiency of information resources on Internet

\begin{tabular}{|c|c|c|c|}
\hline Evaluation index & Evaluation index & Evaluation content & Rank and score \\
\hline \multirow{11}{*}{$\begin{array}{l}\text { Website construction } \\
\text { investment } \\
\text { (weight: } 0.42 \text { ) }\end{array}$} & \multirow{4}{*}{$\begin{array}{c}\text { Website } \\
\text { construction cost } \\
\text { (weight: } 0.26 \text { ) }\end{array}$} & $\begin{array}{l}\text { Construction scale } \\
\text { (weight: } 0.18 \text { ) }\end{array}$ & $\begin{array}{l}\text { medium } \\
6.34\end{array}$ \\
\hline & & $\begin{array}{c}\text { Function } \\
\text { construction } \\
\text { (weight: } 0.35 \text { ) }\end{array}$ & $\begin{array}{c}\text { medium } \\
6.42\end{array}$ \\
\hline & & $\begin{array}{c}\text { Technology } \\
\text { investment } \\
\text { (weight: } 0.25 \text { ) }\end{array}$ & $\begin{array}{c}\text { medium } \\
6.72\end{array}$ \\
\hline & & $\begin{array}{l}\text { Website promotion } \\
\text { (weight: } 0.22 \text { ) }\end{array}$ & $\begin{array}{l}\text { medium } \\
6.6\end{array}$ \\
\hline & \multirow{4}{*}{$\begin{array}{c}\text { Information } \\
\text { development cost } \\
\text { (weight: } 0.62 \text { ) }\end{array}$} & $\begin{array}{l}\text { News information } \\
\text { (weight: } 0.15 \text { ) }\end{array}$ & $\begin{array}{c}\text { medium } \\
6.38 \\
\end{array}$ \\
\hline & & $\begin{array}{l}\text { Science and } \\
\text { technology } \\
\text { information } \\
\text { (weight: } 0.28 \text { ) }\end{array}$ & $\begin{array}{l}\text { medium } \\
6.84\end{array}$ \\
\hline & & $\begin{array}{l}\text { Policy information } \\
\text { (weight: } 0.20 \text { ) }\end{array}$ & $\begin{array}{l}\text { medium } \\
6.52\end{array}$ \\
\hline & & $\begin{array}{l}\text { Market information } \\
\text { (weight: } 0.37 \text { ) }\end{array}$ & $\begin{array}{c}\text { medium } \\
6.76 \\
\end{array}$ \\
\hline & \multirow{3}{*}{$\begin{array}{l}\text { The external cost } \\
\text { (weight: } 0.12 \text { ) }\end{array}$} & $\begin{array}{c}\text { Internet penetration } \\
\text { rate } \\
\text { (weight: } 0.46 \text { ) }\end{array}$ & $\begin{array}{l}\text { medium } \\
6.46\end{array}$ \\
\hline & & $\begin{array}{l}\text { Per capita GDP } \\
\text { (weight: } 0.26 \text { ) }\end{array}$ & $\begin{array}{l}\text { low } \\
5.76\end{array}$ \\
\hline & & $\begin{array}{c}\text { Information } \\
\text { technology talents } \\
\text { (weight: } 0.28 \text { ) }\end{array}$ & $\begin{array}{l}\text { medium } \\
6.3\end{array}$ \\
\hline \multirow{7}{*}{$\begin{array}{l}\text { The site of final } \\
\text { output } \\
\text { (weight: } 0.58 \text { ) }\end{array}$} & \multirow{3}{*}{$\begin{array}{l}\text { Information } \\
\text { dissemination effect } \\
\text { (weight: } 0.48 \text { ) }\end{array}$} & $\begin{array}{c}\text { The average daily } \\
\text { traffic } \\
\text { (weight: } 0.32 \text { ) }\end{array}$ & $\begin{array}{c}\text { medium } \\
6.24\end{array}$ \\
\hline & & $\begin{array}{l}\text { Daily views } \\
\text { (weight: } 0.36 \text { ) }\end{array}$ & $\begin{array}{c}\text { medium } \\
6.12 \\
\end{array}$ \\
\hline & & $\begin{array}{l}\text { Website ranking } \\
\text { (weight: } 0.32 \text { ) }\end{array}$ & $\begin{array}{c}\text { medium } \\
6.34\end{array}$ \\
\hline & \multirow{4}{*}{$\begin{array}{c}\text { The user behavior } \\
\text { effect } \\
\text { (weight: } 0.52 \text { ) }\end{array}$} & $\begin{array}{l}\text { The website visit rate } \\
\text { (weight: } 0.38 \text { ) }\end{array}$ & $\begin{array}{l}\text { medium } \\
6.2\end{array}$ \\
\hline & & $\begin{array}{l}\text { The completeness of } \\
\text { the contents of } \\
\text { satisfaction } \\
\text { (weight: } 0.19 \text { ) }\end{array}$ & $\begin{array}{c}\text { medium } \\
6.3\end{array}$ \\
\hline & & $\begin{array}{l}\text { Practical satisfaction } \\
\text { (weight: } 0.21 \text { ) }\end{array}$ & $\begin{array}{l}\text { medium } \\
6.05\end{array}$ \\
\hline & & $\begin{array}{l}\text { Content update } \\
\text { frequency } \\
\text { satisfaction } \\
\text { (weight: } 0.22 \text { ) }\end{array}$ & $\begin{array}{c}\text { medium } \\
6.68\end{array}$ \\
\hline
\end{tabular}

3) Calculate each index score

According to the method of calculating the index score described above, calculated each index score, with two level indicators website construction cost (B1) as an example: website construction cost is 
determined by the function construction, the technical construction, the scale of construction and website publicity four level three indexes $(\mathrm{C} 1, \mathrm{C} 2, \mathrm{C} 3$, ) grade $\mathrm{B} 1=\mathrm{C} 1$ score $* \mathrm{C} 1$ weight coefficient $+\mathrm{C} 2$ score $\mathrm{x}$ $\mathrm{C} 2$ weight coefficient $+\mathrm{C} 3$ score $\mathrm{x} C 3$ weight coefficient. By the same token level indicators (indicated by A1) can also be obtained.

Shown in table $2-2, \mathrm{~B} 1=0.18 * 6.34+0.35 * 6.42+0.25 * 6.72+0.22 * 6.6=6.52$, similarly calculated, $\mathrm{B} 2=6.68, \mathrm{~B} 3=6.3$. The site of final output level three index scores $\mathrm{B} 4=6.3, \mathrm{~B} 5=6.3$.

The final level indicators $(\mathrm{A} 1, \mathrm{~A} 2)$ score was equal to $\mathrm{A} 1=6.52 * 0.26+6.68 * 0.62+6.3 * 0.12=6.6$, $\mathrm{A} 2=6.3 * 0.48+6.3 * 0.52=6.3$

The final score of $=6.6 * 0.42+0.58 * 6.3=6.43$.

\section{Conclusions}

The construction investment of agriculture website in Guizhou province is the middle level. From the statistical analysis, the Guizhou government departments at all levels should attach great importance to the agricultural website or construction work.

The output efficiency of agricultural web site in Guizhou province is low, although the website construction has become a certain scale, but the conversion rate of agricultural website information resources in Guizhou Province, output efficiency is still low.

The utilization rate of agricultural information resources on the Internet is low in Guizhou province. Through the analysis of statistical data, the input and output model, the utilization rate of score of agricultural information resources on Internet in Guizhou Province is 6.41 points, the overall level is not high, and the input is greater than the output.

\section{References}

[1] Sunyanlin, Zhaozhuoning. Internet agricultural information resources evaluation in the West [M]. Chinese Economic Press, 2007.

[2] Sunyanlin, Zhaozhuoning, Liyangxu. Research of utilization efficiency of online agricultural information resource development in Western [J]. The work of library and information, 2010.

[3] Xiongxiaoyun, Sunyanlin. The efficiency evaluation model, method and empirical research on the use of network information resources[J]. Journal of information, 2009.

[4] Lidaoliang. The report of Chinese rural informatization development [M]. Beijing Institute of Technology press, 2010.

[5] Baowaly M K, Bhuiyan M. Accessibility analysis and evaluation of Bangladesh Government Websites[C]//Informatics, Electronics \&Vision (ICIVE). New York, 2012. 